\title{
Effect of organic and inorganic fertilizer on the growth and yield of sorghum (Sorghum bicolor (L.) Moench) in Bauchi state, Nigeria
}

\author{
Shuaibu Yunusa Muhammad *, Bala Rashida Abdulmumini, Kawure Sani and Shuaibu Zaharaddeen \\ Department of Crop Production, Faculty of Agriculture and Agricultural Technology, Abubakar Tafawa Balewa University \\ Bauchi, Nigeria.
}

Publication history: Received on 30 October 2017; revised on 19 November 2017; accepted on 11 January 2018

https://doi.org/10.30574/gscbps.2018.2.1.0053

\begin{abstract}
The field experiment was conducted at the Abubakar Tafawa Balewa University Bauchi teaching and research farm during the rainy season of 2016. Bauchi state belongs to savannah agro-ecological zone and geographically located between latitude $10^{\circ} 74^{\prime} \mathrm{E}$ and $9^{\circ} 47^{\prime} \mathrm{E}$ and $690.3 \mathrm{~m}$ above the sea level. The experiment was conducted to determine the effect of organic and inorganic fertilizer on the growth and yield of sorghum. The design used for the experiment was randomized complete block design (RCBD) and replicated three times. The treatment consisted of three levels of cow manure (0,1 and 2 ton/ha) and four levels of NPK 15:15:15 (0,15, 30 and $45 \mathrm{~kg} / \mathrm{ha})$, these were factorially combined to give 12 treatment combinations. The result of the experiment indicated that, there is a significant $(\mathrm{P} \leq 0.05)$ difference among the treatment used. It was further revealed that, application of NPK fertilizer at the rate of $45 \mathrm{~kg} / \mathrm{ha}$ and 2 ton/ha cow manure was found to be significantly $(\mathrm{P} \leq 0.05)$ better than other treatments and all the treatment were better than control. It was observed that the combination of $45 \mathrm{~kg} \mathrm{NPK} / \mathrm{ha}$ and 2 ton cow manure/ha was found to be significantly better than other treatment. Based on the finding of this study, it can be recommended that the application of $45 \mathrm{~kg} \mathrm{NPK} /$ ha in combination with 2 ton cow manure/ha should be adopted by farmers in the study area for sustainable sorghum production.
\end{abstract}

Keywords: Sorghum; Fertilizer; Yield; Growth

\section{Introduction}

The major constrain to productivity of crops in the semi-arid region is inadequate, unreliable and poorly distributed rainfall and low soil fertility especially ( $\mathrm{N}$ and $\mathrm{P}$ ). The limited use of mineral and organic fertilizer on crop is due to limited resources by the farmers and the risk associated with fertilization in the environment of low and uncertain rainfall. The importance of integrated use of organic and inorganic nutrient sources in the semi-arid tropics have been reported [1]. Organic sources such animal manure is an effective source of major nutrient (N, P, and K) when applied at optimum rates and can influence the temporal dynamics of nutrients availability [2], increase water use efficiency of crops [3], decrease phosphorous fixation and enhance its availability in the soils through its effects on physical and chemical properties of the soil [4]. Despite all these, a complementary application of mineral fertilizer is usually required for a good nutrient balance.

Intensive farming with fertilizer responsive crop rely on high application of inorganic fertilizer, this is very expensive and pose a serious threat to soil health and ground water. Entire dependence on organic sources of nutrient may not be adequate for good productivity. Soil fertility decline is caused by the interaction of natural and managerial factors, usually through leaching, soil erosion and crop removal. The steady decline in food production observed over the years 
has been attributed to the decline in soil fertility [5]. Unless the nutrient are replenished through the use of organic or mineral fertilizers or through traditional fallow system that allows restoration of nutrient and reconstitution of soil organic matter, the food security in the semi-arid region will not be achieved. Majority of the farmers in the study area are subsistence and cannot afford the required amount of inorganic fertilizer, due to cost associated with transporting huge amount of organic fertilizer and lack of information on the inappropriate combining ratio of organic and inorganic fertilizer in sorghum production. This lead to significant low yield in sorghum production due to poor soil fertility which is the limiting factor for optimum yield of sorghum. Soil degradation which is brought about by loss of organic matter as a result of continuous cropping become aggravated when inorganic fertilizers are solely applied repeatedly [6].

Sorghum is an important crop worldwide used for food (as grain and in sorghum syrup), fodder, alcoholic beverages and bio-fuels. Sorghum is adapted to a wide range of environmental condition but is particularly adapted to drought. Most research work show that the use of several organic materials especially Cow dung, poultry manure and farmyard manure as soil amendment for increasing crop production particularly among subsistence farmers with inorganic fertilizer. However the benefit derivable from the use of organic materials has not been utilized fully in the northern guinea savannah mainly due to large amount of organic materials required in order to satisfy the nutritional need of the crops [7]. Therefore this study was carried out to study the best rates of application of cow dung, best level of application of inorganic fertilizer and the best combination of organic and inorganic fertilizer on the growth and yield of sorghum.

\section{Material and methods}

The experiment was conducted during the rainy season of 2016 at Abubakar Tafawa Balewa University teaching and research farm Bauchi, to determine the responds of sorghum to organic and inorganic fertilizer. The treatments consisted of four levels of inorganic fertilizer (NPK 15: 15: 15) 0, 15, 30 and $45 \mathrm{~kg} / \mathrm{ha}$ and three levels of organic fertilizer (cow dung) 0,1 and 2 ton/ha. These were factorially combined to give 12 treatment combinations. The design used for the experiment was randomized complete block design (RCBD) and replicated three times. The data collected for the experiment were plant height, number of leaves, leaf area, panicle length, number of spike per panicle, grain weight (1000 seed) and grain yield. Analysis of variance (ANOVA) was used in data analysis and Duncan's multiple range test (DMRT) was used to separate the means.

\section{Result and discussion}

\subsection{Effect of organic and inorganic fertilizer on growth characters of sorghum}

\subsubsection{Effects of NPK fertilizer and cow dung on plant height of sorghum}

Table 1 Effect of organic and inorganic fertilizer on plant height of sorghum

\begin{tabular}{lccccc}
\hline Treatments & $\mathbf{2}$ & $\mathbf{4}$ & $\mathbf{W A S}$ & $\mathbf{8}$ & $\mathbf{1 0}$ \\
\hline NPK (kg/ha) & & & & & \\
0 & $10.94^{\mathrm{d}}$ & $33.01^{\mathrm{d}}$ & $59.48^{\mathrm{d}}$ & $85.01^{\mathrm{d}}$ & $136.92^{\mathrm{d}}$ \\
15 & $12.2^{\mathrm{c}}$ & $41.92^{\mathrm{c}}$ & $79.56^{\mathrm{c}}$ & $143.13^{\mathrm{c}}$ & $189.69^{\mathrm{c}}$ \\
30 & $13.17^{\mathrm{b}}$ & $47.30^{\mathrm{b}}$ & $83.90^{\mathrm{b}}$ & $140.13^{\mathrm{b}}$ & $215.57^{\mathrm{b}}$ \\
45 & $14.23^{\mathrm{a}}$ & $53.12^{\mathrm{a}}$ & $96.13^{\mathrm{a}}$ & $181.35^{\mathrm{a}}$ & $280.83^{\mathrm{a}}$ \\
LS & $* *$ & $* *$ & $* *$ & $* *$ & $* *$ \\
SE \pm & 0.14 & 1.30 & 1.12 & 0.78 & 8.32 \\
\hline Cow Dung (ton/ha) & & & & & \\
0 & $12.29 \mathrm{c}$ & $40.04^{\mathrm{c}}$ & $73.76^{\mathrm{c}}$ & 137.84 & 203.18 \\
1 & $12.80^{\mathrm{b}}$ & $44.02^{\mathrm{b}}$ & $80.84^{\mathrm{b}}$ & 136.09 & 207.96 \\
2 & $13.22^{\mathrm{a}}$ & $47.44^{\mathrm{a}}$ & $84.69^{\mathrm{a}}$ & 138.27 & 206.12 \\
LS & $* *$ & $* *$ & $* *$ & $\mathrm{NS}$ & $\mathrm{NS}$ \\
SE \pm & 0.12 & 1.12 & 0.97 & 0.68 & 7.2 \\
\hline Interaction & & & & & $* *$ \\
CD X NPK & $* *$ & $* *$ & $* *$ & $* *$ & $* *$ \\
\hline
\end{tabular}

Means followed by the same letter in a column are not significantly different following DMRT. SE= standard error, ${ }^{* *}=(\mathrm{P} \leq 0.01), \mathrm{LS}=$ level of significance, WAS $=$ Weeks after sowing, NS $=$ Not significant . 
Table 1, showed the effect of organic and inorganic fertilizer on plant height of sorghum. The result revealed that, 45 $\mathrm{kg} / \mathrm{ha}$ NPK and 2 ton/ha cow dung was significantly $(\mathrm{P} \leq 0.05)$ observed to be better in terms of plant height throughout the study period. The result further revealed a significant $(\mathrm{P} \leq 0.05)$ difference between levels of organic and inorganic fertilizers, however all the treatments were found to be better than the control. The significant $(\mathrm{P} \leq 0.05)$ difference observed throughout the study period on plant height of sorghum in which the rate of $45 \mathrm{~kg} / \mathrm{ha}$ NPK proved to be better than all the rates used, indicated that, increased in rate of NPK fertilizer increased growth of sorghum. It further indicated that, the application of 2 ton/ha cow dung was found to be better than other rate. The increase in plant height could be as a result of increase in optimal efficiency of fertilizer used. This is in line with the result of [8], who reported that application of cow manure alone or in combination with urea significantly increased the plant height of sorghum. The result also lend its support to the findings of [9], who reported that there is a significant effect of nitrogen on growth of sorghum. The interaction of cow dung and NPK showed that $45 \mathrm{~kg} / \mathrm{ha}$ NPK combined with 2 ton/ha cow dung significantly produced tallest plants than the other treatments used. This conform with the report of [10] who reported that, the quantity of soil organic matter in the soil has been found to depend on the quantity of organic material which can be introduce in to the soil either by natural return through roots, stubble, root noodles and roots exudate or by artificial application in form of organic manure.

\subsubsection{Effects of NPK fertilizer and cow dung on number of leaves of sorghum}

The result in table 2 showed the effect of organic and inorganic fertilizer on number of leaves of sorghum, the result revealed a significant $(\mathrm{P} \leq 0.05)$ difference among the treatments used on number of leaves of sorghum. The result further revealed that, application of $45 \mathrm{~kg} \mathrm{NPK} /$ ha was found to be statistically $(\mathrm{P} \leq 0.05)$ better than the other rates and all the rates were better than the control. Cow dung on the other hand, application of 2 ton/ha proved to be significantly $(\mathrm{P} \leq 0.05)$ better than the other rates used and all the rates were better than the control. The result of the interaction showed that application of $45 \mathrm{~kg} \mathrm{NPK} /$ ha combined with 2 tons cowdung/ha significantly $(\mathrm{P} \leq 0.05)$ produced highest number of leaves of sorghum throughout the study period. The significant $(\mathrm{P} \leq 0.05)$ difference observed throughout the study period on number of leaves of sorghum in which the rate of $45 \mathrm{~kg} / \mathrm{ha}$ NPK proved to be better than all the rates used, this indicate that increased in rate of NPK fertilizer increased growth of sorghum. It further indicated that the application of 2 ton/ha cow dung was found be superior to other rate. This collaborate with the finding of [11] who reported that difference in NPK use efficiency were related to increase in number of leaves of sorghum.The importance of organic matter was reported by many scientists. [12], indicated that the soil organic matter play an essential role in maintaining the stability of soil aggregates. [13], stated that the main constituent of soil organic matter are humus substance, which together with polysaccharides, are active ingredient for aggregation. The interaction of cow dung and NPK in which $45 \mathrm{k} /$ ha NPK plus 2 ton/ha cowdung significantly produced highest number of leaf than other treatment used.

Table 2 Effect of organic and inorganic fertilizer on number of leaves of sorghum

\begin{tabular}{lccccc}
\hline \multirow{2}{*}{ Treatments } & \multicolumn{3}{c}{ WAS } & $\mathbf{6}$ & $\mathbf{1 0}$ \\
\cline { 2 - 5 } NPK (kg/ha) & $\mathbf{2}$ & $\mathbf{4}$ & $\mathbf{6}$ & & \\
0 & $4.78 \mathrm{~d}$ & $7.33 \mathrm{c}$ & $8.88 \mathrm{~d}$ & $8.88 \mathrm{~d}$ & $11.78 \mathrm{~d}$ \\
15 & $5.67 \mathrm{c}$ & $8.22 \mathrm{~b}$ & $9.89 \mathrm{c}$ & $10.78 \mathrm{c}$ & $12.67 \mathrm{c}$ \\
30 & $6.22 \mathrm{~b}$ & $8.56 \mathrm{~b}$ & $10.56 \mathrm{~b}$ & $11.57 \mathrm{~b}$ & $13.56 \mathrm{~b}$ \\
45 & $7.00 \mathrm{a}$ & $10.22 \mathrm{a}$ & $12.22 \mathrm{a}$ & $13.33 \mathrm{a}$ & $15.89 \mathrm{a}$ \\
LS & $* *$ & $* *$ & $* *$ & $* *$ \\
SE & 0.12 & 0.24 & 0.17 & 0.54 & 0.11 \\
\hline Cow Dung (ton/ha) & & & & $10.35 \mathrm{c}$ & 13.33 \\
0 & $5.58 \mathrm{~b}$ & $8.08 \mathrm{~b}$ & $10.00 \mathrm{~b}$ & $11.57 \mathrm{~b}$ & 13.32 \\
1 & $6.22 \mathrm{a}$ & $8.50 \mathrm{~b}$ & $10.50 \mathrm{a}$ & $13.33 \mathrm{a}$ & 13.67 \\
2 & $6.08 \mathrm{a}$ & $9.17 \mathrm{a}$ & $10.67 \mathrm{a}$ & 13 & $\mathrm{NS}$ \\
LS & $* *$ & $* *$ & $*$ & 0.15 & 0.09 \\
\hline
\end{tabular}

Interaction

CD X NPK

NS

$*$

$* *$

$* * \quad * *$

Means followed by the same letter within the same column are not significantly different following DMRT. $\mathrm{SE}=$ standard error, $^{*}=(\mathrm{P} \leq 0.05)$ and ${ }^{* *}=$ $(\mathrm{P} \leq 0.01), \mathrm{LS}=$ level of significance, WAS = Weeks after sowing, NS = Not significant. 


\subsubsection{Effects of NPK fertilizer and cow dung on leaf area of sorghum}

The result as presented in table 3 revealed the effect of organic and inorganic fertilizer on leaf area of sorghum. The result showed that, application of $45 \mathrm{~kg} \mathrm{NPK} /$ ha significantly $(\mathrm{P} \leq 0.05)$ produced highest leaf area throughout the study period. Similarly, the application of 2 ton cowdung/ha significantly $(\mathrm{P} \leq 0.05)$ produced higher leaf area than the other rates and all the rates were better than the control. The result of the interaction revealed that, combination of $45 \mathrm{~kg}$ NPK /ha and 2 tons cowdung/ha was found to be significantly $(\mathrm{P} \leq 0.05)$ better than other treatments used. The significant $(\mathrm{P} \leq 0.05)$ difference observed throughout the study period on leaf area of sorghum in which the rate of 45 $\mathrm{kg} /$ ha NPK proved to be better than all the rates used, indicated the importance of inorganic fertilizer in promoting leaf area of sorghum. This further proved that increased in rate of NPK fertilizer increased growth of sorghum. It further indicated that the, application of 2 ton/ha cow dung was found be superior to other rate. This revealed the importance of combine application of organic and inorganic fertilizer. The increase in leaves area as observed in this study could be as a result of increase in application of organic and inorganic fertilizer. This agreed with the findings of [14], who reported that manure alone or mixed with N.P.K result in an increase in growth and yield of sorghum.

Table 3 Effect of organic and inorganic fertilizer on leaf area of sorghum

\begin{tabular}{|c|c|c|c|}
\hline \multirow{2}{*}{ Treatments } & \multicolumn{3}{|c|}{ WAS } \\
\hline & 4 & 6 & 8 \\
\hline \multicolumn{4}{|l|}{ NPK (kg/ha) } \\
\hline 0 & $54.47 \mathrm{~d}$ & $179.14^{\mathrm{b}}$ & $218.23^{d}$ \\
\hline 15 & $81.42^{c}$ & $285.83^{a}$ & $297.53^{c}$ \\
\hline 30 & $100.91^{b}$ & $285.51^{\mathrm{a}}$ & $340.22^{b}$ \\
\hline 45 & $120.80^{a}$ & $248.16^{\mathrm{a}}$ & $415.12^{\mathrm{a}}$ \\
\hline LS & $* *$ & $* *$ & $* *$ \\
\hline $\mathrm{SE} \pm$ & 3.15 & 19.55 & 5.10 \\
\hline \multicolumn{4}{|c|}{ Cowdung (ton/ha) } \\
\hline 0 & $85.02^{c}$ & 220.64 & $286.99^{b}$ \\
\hline 1 & $187.34^{b}$ & 258.30 & $329.04^{\mathrm{a}}$ \\
\hline 2 & $195.85^{\mathrm{a}}$ & 267.65 & $337.34^{\mathrm{a}}$ \\
\hline LS & $*$ & NS & $* *$ \\
\hline $\mathrm{SE} \pm$ & 2.73 & 16.85 & 4.42 \\
\hline \multicolumn{4}{|l|}{ Interaction } \\
\hline
\end{tabular}

Means followed by the same letter within a column are not significantly different following DMRT. SE $=$ standard error, ${ }^{*}=(\mathrm{P} \leq 0.05)$ and ${ }^{* *}=$ $(\mathrm{P} \leq 0.01), \mathrm{LS}=$ level of significance, WAS $=$ Weeks after sowing, NS = Not significant.

\subsection{Effect of organic and inorganic fertilizer on yield and yield components of sorghum}

\subsubsection{Panicle length $(\mathrm{cm})$}

Table 4 showed the effect of organic and inorganic fertilizer on panicle length of sorghum. The result revealed that the application of $45 \mathrm{~kg} /$ ha NPK and 2 ton/ha was observed to produce significantly $(\mathrm{P} \leq 0.05)$ longer head than the other treatment used. With control having the shortest head among the treatments used. This indicates the importance of NPK fertilizer as a basic component of plant physiological activities. The interaction of cowdung and NPK fertilizer indicated that, combine application of $45 \mathrm{~kg} \mathrm{NPK} /$ ha and 2tons cowdung/ha gave significantly $(\mathrm{P} \leq 0.05)$ highest panicle length. This revealed the importance of combine application of organic and inorganic fertilizer in sorghum production. This corroborate with the findings of [15] who reported that cow mature gave taller plant height, number of leave per plant and increasing the yield and yield component of sorghum.

\subsubsection{Number of spikes per panicle}

The result as presented in table 4 showed the effect of organic and inorganic fertilizer on number of spike per panicle of sorghum. The result revealed that, application of $45 \mathrm{~kg} \mathrm{NPK} /$ ha and 2 ton/ha cowdung significantly $(\mathrm{P} \leq 0.05)$ had a highest number of spikes per panicle than other treatment and all the treatments were better than the control. The significant $(\mathrm{P} \leq 0.05)$ difference observed in this experiment indicated the significance of inorganic fertilizer on number 
of spikes of sorghum. This further revealed the effects of combine application of NPK and cowdung on yield of sorghum. The result of this study is in line with the report of [11], who found that the grain sorghum yield responds to organic and inorganic fertilizer combination. It is also in conformity with the report [16] who reported that little organic manure combined with inorganic fertilizer contain considerable amount of organic matter, hence has an effect in soil $\mathrm{pH}$.

\subsubsection{Grain weight (1000 seeds)}

Table 4 showed the effect of organic and inorganic fertilizer on grain weight (1000 seeds) of sorghum. The result showed that application of $45 \mathrm{~kg}$ NPK and 2 ton/ha cowdung was observed to had a significantly $(\mathrm{P} \leq 0.05)$ highest 1000 grain weight than other treatments. The result of this study revealed that, application of inorganic and organic fertilizer has an effect on 1000-grain weight of sorghum. This supported the finding of [17], who observed a significant increase in 1000 -grain weight due to the addition of $45 \mathrm{~kg} / \mathrm{ha}$ NPK. It is also in agreement with that of [18], who found significant increase in grain-weight with increase in inorganic fertilizer rates.

\subsubsection{Grain Yield (ton/ha)}

The result in table 4 showed the effect of organic and inorganic fertilizer on grain yield of sorghum. The result revealed that application of $45 \mathrm{~kg}$ NPK was found to produced significantly $(\mathrm{P} \leq 0.05)$ higher yield than other treatments used. Control on the other hand having the lowest yield among the treatment considered. It further revealed that application of 2 ton/ha cowdung was observed to significantly $(\mathrm{P} \leq 0.05)$ produced higher yield than the other rates. The yield of sorghum increase with the increase in level of fertilizer application. This revealed the importance of organic and inorganic fertilizer application in sorghum production. This indicates the effect of nitrogen as a basic compound of much physiological process in plants. This supported the finding of [19] who reported that higher application of manure will positively affect soil fertility in sorghum production, reported that application of FYM and urea to the soil significantly increased total nitrogen content of the top $30 \mathrm{~cm}$ of the soil. This indicated that, combine application of organic and inorganic fertilizer is a best way of reducing negative effect of solely use of inorganic fertilizer as sources of nutrients to crop production. The higher grain yield obtained could be due to balance in the proportion of nutrients in adequate amount. It can also be due to improvement in soil fertility, temperature and the amount of spread rainfall received during the study. This is in conformity with the report of [11] who indicated that the grain sorghum responded to organic and inorganic fertilizer by increase in yield. High nitrogen increases sorghum yield as reported by [20 and 11]. The result of this study also lend its support from the report of [21], reported that the difference in NPK use efficiency were related to grain yield of sorghum to applied NPK.

Table 4 Effect of organic and inorganic fertilizer on yield and yield components of sorghum

\begin{tabular}{|c|c|c|c|c|}
\hline \multirow[t]{2}{*}{ Treatments } & \multicolumn{4}{|c|}{ Parameters } \\
\hline & No: of spike/ panicle & Panicle length (cm) & Grain weight (g) & Yield (ton/ha) \\
\hline \multicolumn{5}{|l|}{ NPK (kg/ha) } \\
\hline 0 & $104.58^{\mathrm{b}}$ & $34.15^{c}$ & $24.33^{c}$ & $1.38^{c}$ \\
\hline 15 & $120.01^{\mathrm{a}}$ & $39.58^{\mathrm{b}}$ & $29.78^{\mathrm{ab}}$ & $2.17^{\mathrm{b}}$ \\
\hline 30 & $117.45^{\mathrm{a}}$ & $39.80^{b}$ & $29.57^{b}$ & $2.17^{\mathrm{b}}$ \\
\hline 45 & $122.78^{\mathrm{a}}$ & $42.92^{\mathrm{a}}$ & $32.11^{\mathrm{a}}$ & $3.36^{\mathrm{a}}$ \\
\hline LS & $* *$ & $* *$ & $* *$ & $* *$ \\
\hline SE \pm & 2.69 & 0.85 & 0.82 & 0.13 \\
\hline \multicolumn{5}{|c|}{ Cow dung (ton/ha) } \\
\hline 0 & 114.43 & $37.60^{\mathrm{b}}$ & $27.50^{c}$ & 2.21 \\
\hline 1 & 117.18 & $39.78^{a}$ & $30.00^{\mathrm{a}}$ & 3.30 \\
\hline 2 & 117.01 & $40.37^{a}$ & $29.33^{b}$ & 2.30 \\
\hline LS & NS & $*$ & $*$ & NS \\
\hline $\mathrm{SE} \pm$ & 2.33 & 0.84 & 0.71 & 0.11 \\
\hline \multicolumn{5}{|l|}{ Interaction } \\
\hline CD X NPK & $*$ & $*$ & $*$ & $* *$ \\
\hline
\end{tabular}


Table 5 Interaction of NPK fertilizer and cow manure on grain yield and 1000 seed weight of sorghum

\begin{tabular}{|c|c|c|c|c|c|c|}
\hline \multirow[t]{3}{*}{ Treatments } & \multicolumn{6}{|c|}{ Cowdung (ton/ha) } \\
\hline & $\mathbf{0}$ & 1 & 2 & $\mathbf{0}$ & 1 & 2 \\
\hline & \multicolumn{3}{|c|}{ Grain Yield (ton/ha) } & \multicolumn{3}{|c|}{ Grain weight (1000 seeds) } \\
\hline \multicolumn{7}{|l|}{ NPK (kg/ha) } \\
\hline 0 & $0.70^{\mathrm{f}}$ & $1.69 \mathrm{e}$ & $1.73^{\mathrm{e}}$ & $20.33 \mathrm{~g}$ & $25.00^{f}$ & $27.67^{\mathrm{e}}$ \\
\hline 15 & $3.06^{\mathrm{b}}$ & $1.74^{\mathrm{e}}$ & $1.71^{\mathrm{e}}$ & $31.33^{b}$ & $28.67^{d}$ & $29.33^{c}$ \\
\hline 30 & $2.39 \mathrm{~d}$ & $2.41^{\mathrm{d}}$ & $1.72^{\mathrm{e}}$ & $28.67^{d}$ & $32.33^{\mathrm{b}}$ & $27.67^{e}$ \\
\hline 45 & $2.68^{c}$ & $3.36^{\mathrm{b}}$ & $4.04^{\mathrm{a}}$ & $29.67^{c}$ & $34.00^{\mathrm{a}}$ & $32.67^{a}$ \\
\hline LS & \multicolumn{3}{|c|}{$*$} & \multicolumn{3}{|c|}{$* *$} \\
\hline $\mathrm{SE} \pm$ & \multicolumn{3}{|c|}{0.24} & \multicolumn{3}{|c|}{0.89} \\
\hline
\end{tabular}

\section{Conclusion}

In conclusion however, the application of $45 \mathrm{~kg} / \mathrm{ha} \mathrm{NPK}+2$ ton cow dung/ha produced the best result in both growth and yield characters throughout the study period. Based on the result of this study, the following recommendations were made:

- Application of $45 \mathrm{~kg} / \mathrm{ha}$ NPK with 2 ton/ha cow manure can be recommended.

- Sorghum growth and yield increase with increase of rate of both organic and inorganic fertilizer.

\section{Compliance with ethical standards}

\section{Acknowledgments}

All praises are due to Almighty God for His infinite mercy in sparing our lives and enabling us to reach the conclusion of this research work. We express our gratitude to all the staff of Department of Crop Production in particular, Faculty of Agriculture and the entire Abubakar Tafawa Balewa University in general. It is imperative to appreciate the contribution of Bauchi State Agricultural Development Programme (BSADP) for their support during the conduct of this research.

\section{Disclosure of conflict of interest}

The authors of this article declared that there is no conflict of interest.

\section{References}

[1] Damodar G, Reddy D, Subba RA, Sammi KR and Takkar PN. (1999). Yield sustainability and phosphorus utilization in soybean-wheat system on vertisols in response to integrated use of manure and fertilizer phosphorus. Field crops research, 62, 181-90

[2] Paul TTW and Beauchamp EG. (1993). Nitrogen availability for corn in soil amended with urea, cattle slurry, and solid and composted manure. Canadian Journal of soil science, 73(6), 709-711

[3] Carter DC, Harris D, Youngquist JB and Persaud N. (1992). Soil properties, crop water use and cereals yield in Botswana after addition of mulch and manure. Field crops Research, 30, 97-109

[4] Lyamuremye F and Dick RP. (1996). Organic amendment and phosphorus sorption by soil. Advances in Agronomy, 56, 139-85

[5] Denova G and Casey C. (1998). Soil fertility management in sub-sahara Africa, phosphorus and nitrogen base manure and compost application. Agronomy journal, 94, 128 -135.

[6] FAO (2011). Sorghum production and trade http//www.sorghumgrowers.com 
[7] Lopez U, Masquera ME, Cabeleiro F, Sainz MS, Lopezfabal A, Cerral E. (2008). Fertilizing value of broilers linters: Effect of drying and pelletizing. Bio-resource fechol, 99, 5626-5633

[8] Ayoola OT and Adeniyan ON. (2008). Influence of poultry manure and NPK fertilizer on yield component of crops under different cropping system in south-west Nigeria. African journal of biotechnology, 5(15), 1386-1392

[9] Elghball B. (2002). Soil properties as influence by phosphorus and nitrogen-base manure and compost applications. Agronomy journal, 94, 1128-135

[10] Feisal M, Ismaeil AO and Abusuwar AME. (2012). Influence of Chicken manure on growth and yield of forage sorghum (Sorghum bicolor L. moench). International Journal of Agriculture and Forestry, 2(2), 56-60

[11] Conley SP, Steven WG and Dunn DD. (2005). Grain sorghum responds to row spacing, plant density and planter skips. Crop management, 5, 56- 59

[12] Beckwith RS. (2002). Sorbed phosphorus at standard supernatant concentration as an estimate of the phosphoric needs of the soil. Australian Journal of Experimental Agriculture, 5(3), 52-58

[13] Bendfeldt SH. (2002). Poultry litter as fertilizer and soil Amendment. Associate extension agent, agricultural and natural research, R. A clerk, extension agent Agricultural and natural resources. 5, 56- 580

[14] Aflakpul GSK, Anchirinah VM and Asumadu H. (2005). Respond of quality protein maize hybrid to N supply and plant density in the forest zone of Ghana, Tropical. Science, 45, 3-7

[15] Gambara P, Mechemedze T and Mewenye D. (2002). Soil fertility project, annual report 1998-1999 unpublished report AGRITEX, Marondera Zimbabwe.

[16] Mullins LG and Benefeldt ES. (2002). Poultry litter as soil amendment, crop and soil environmental science. Association extension agent agricultural and natural resources, Virginia tech. Publication number 423-534 posted January 2002.

[17] Mafongoya PL, Bationo A, Kihara J and Swaswa B. (2006). Appropriate technologies to replenish soil fertility in southern Africa. Nutrition cycle agroecogyst, 76, 137 - 151.

[18] Chaudhary EH, Ranjha AM, Gill AM and Mehdi SM. (2003). Phosphorus requirement of maize in relation to soil characteristic. International Journal of agricultural Biology, 5(4), 625-629

[19] Ibrahim SH, Moamed AB, Osman HN and Hashim M. (2002). Fertilizing with urea and FYM for higher cotton yield and better soil condition in Gezira. Crop husbandry committee meeting, 2002, ARC, wad medanisudan.

[20] Lafarge TA and Hamma GA. (2002). Tillering in grain sorghum over a wide range of population densities. Modeling dynamic of tiller density. Bot., Journal of Agronomy, 6(9), 99-110

[21] Ogbonna AC. (2007). Sorghum: environmentally friendly food and industrial grain in Nigeria. Nigerian food journal, 5(1), 25-35

\section{How to cite this article}

Shuaibu YM, Bala RA, Kawure S and Shuaibu Z. (2018). Effect of organic and inorganic fertilizer on the growth and yield of sorghum (Sorghum bicolor (L.) Moench) in Bauchi state, Nigeria. GSC Biological and Pharmaceutical Sciences, 2(1), 25-31. 